\title{
Imaging protein conformational space in liquid water
}

\author{
Cesare De Pace 1,2,3,5,\# , Silvia Acosta-Gutierrez1,2,3,5,\#, Gabriel Ing1,2,3,4,5,\# ,Gabriele \\ Marchello1,2,3,4,7,\#,, , Simona Pilotto4,5, Finn Werner4,5, Neil Wilkinson 4,6 , Francesco L. \\ Gervasio 1,5,7,8, Lorena Ruiz-Pérez 1,2,3,5*, and Giuseppe Battaglia1,2,3,8,10* \\ 1Department of Chemistry, 2EPSRC/JEOL Centre for Liquid Phase Electron Microscopy, 3/nstitute for the \\ Physics of Living Systems, ${ }^{4}$ Division of Bioscience, 5 Institute of Structural and Molecular Biology, University \\ College London, UK. ${ }^{6}$ Gatan, UK 7 University of Geneva, Pharmaceutical Sciences, Geneva, Switzerland. \\ 8Institute of Pharmaceutical Sciences of Western Switzerland, University of Geneva, Geneva, Switzerland. \\ 9Institute for Bioengineering of Catalunya (IBEC), The Barcelona Institute of Science and Technology, \\ Barcelona (Spain). 10 Catalan Institution for Research and Advanced Studies (ICREA), Barcelona, Spain. \\ \# These authors have contributed equally \\ "Current address: Italian Institute of Technology, Genova, Italy \\ *Corresponding Authors: Dr Lorena Ruiz-Pérezl.ruiz-perez@ucl.ac.uk and Prof Giuseppe Battaglia q.battaglia@ucl.ac.uk and \\ gbattaglia@ibecbarcelona.eu
}

\begin{abstract}
Recent developments in electron-transparent materials have paved the way for liquid-phase electron microscopy (LPEM) leading to an unprecedented understanding of the structure and dynamics of specimens in their liquid environment. Image reconstruction in liquid-state poses several challenges, and most importantly, it undermines the single-particle analysis assumption that the three-dimensional objects captured on the image sensor are identical. We propose the combination of all-atom simulations with LPEM to complement structural studies with dynamic investigations. In this work, we exploited LPEM to image the dynamics of particles undergoing Brownian motion, using their natural rotation to access the particle structural landscape for reconstructing its architecture in 3D using tomographic techniques. We have selected two test cases for our approach according to prior data accessibility and physiological environment factors: apoferritin and archaeal RNA polymerase. We show that the adopted approach allows to achieve sub-nanometer spatial resolutions of protein structures, either imaging proteins one by one and assessing different conformational states or combining several proteins into one statistical conformational ensemble.
\end{abstract}

\section{Introduction}

Electron microscopy (EM) is one of the most powerful techniques for structure determination with the ability to image matter down to the subatomic level. The short wavelength associated with electrons is pivotal for achieving such a high resolution. However, electrons interact strongly with matter making imaging possible only under ultrahigh vacuum conditions. Such a necessity limits EM imaging to solid-state or non-volatile specimens. Thus samples dispersed in most common liquids or containing liquids, especially water, require special preparation techniques involving either controlled drying or cryogenic treatments with consequent artefacts. Such alterations become particularly critical for biological samples whose meso- and nano-scale structures comprise water as one of the building blocks [1]. Some of these limitations can be overcome using fast vitrification processes to solidify liquid samples [2]. In the last three decades, cryogenic electron microscopy (cryoEM) has radically changed biology [3-7]. A critical step forward in the tremendous advancement of cryoEM has been the development of single-electron detectors and image analysis techniques, such as electron tomography (ET) and single-particle analysis (SPA), for resolving specimens' three-dimensional 
bioRxiv preprint doi: https://doi.org/10.1101/2021.04.30.442083; this version posted April 30, 2021. The copyright holder for this preprint (which was not certified by peer review) is the author/funder, who has granted bioRxiv a license to display the preprint in perpetuity. It is made available under aCC-BY-NC 4.0 International license.

De Pace et al.

Imaging protein conformational space in liquid water

(3D) structure. Structure determination has enabled biologists to shed light on the hierarchical organisation and associated functions of complex biological machinery $[8,9]$. In ET, many specimen two-dimensional (2D) projections or profiles are collected by rotating the samples to different angles $[8,9]$. In SPA the specimen profiles are collected over large number of images containing many particles per field-of-view with the general assumption that all particles are identical or very similar to each other $[4,10]$. For both techniques all the profiles are classified, aligned, refined, and collated together to give form to a 3D structure [11]. A large number of profiles provides high spatial resolution thus making SPA considerably superior to ET, which often is limited to the analysis of large complexes or sub-cellular sections $[8,9]$ which are too large and/or heterogenous for SPA. In the case of proteins, SPA enables atomic reconstruction [12] with tremendous consequences in molecular and chemical biology, and drug discovery [13]. Cryogenic and standard dry TEM provide snapshots of three-dimensional (3D) structural information that can be correlated with function and more recently with close to single angstrom resolution [14-16]. Yet, most biomolecules such as proteins, nucleic acids, or sugars are naturally soft and subjected to thermal fluctuations and internal motion over a broad range of length and time scales. Biomolecules' conformational space is unique to each temperature and environmental conditions and includes several micro-states. Shedding light on the dynamics of biomolecules is critical to understand molecular recognition patterns, enzymatic conversions, and allostery. Thus, it would appear evident that the new frontier of microscopy is the temporal dimension, and the ability to access dynamic changes near physiological temperatures where the molecule of interest operates. While four-dimensional electron microscopy has been proposed with temporal resolutions approaching nanoseconds [17], accessing the biomolecule conformational landscape under physiological conditions is still a major challenge. In cryoEM, rapid sampling $[18,19]$ or appropriate classification during SPA refinement to separate different configurations $[20,21]$ can probe protein conformational states, but the time resolution is limited and the molecules are vitrified at $-180^{\circ} \mathrm{C}$. Physiological conditions can also be achieved using NMR spectroscopy which grants access to the biomolecule structure and dynamics with atomic resolution. However, unlabelled structure determination via NMR is very much restricted to small proteins, with the requirement of incorporating stable isotopes for structures larger than $\sim 100 \mathrm{kDa}$ [22], and often in combination with other methods such as X-ray crystallography or cryoEM imaging [20]. More importantly structure and dynamics determination by NMR require time-consuming chemical shift assignment [22]. These challenges call for a completely new approach to probe biological molecules and materials at physiological temperature and with relevant timescales. The recent development of electron-transparent materials and liquid-phase electron microscopy (LPEM) have enabled the imaging of samples at room temperature and in liquid state [23, 24]. LPEM imaging has been applied to study electrochemical reactions [25], nanocrystal growth $[26,27]$, whole cells $[28,29]$, and to extract atomistic structure of inorganic particles in liquid state $[30,31]$ to name a few applications. Examples of $3 D$ reconstruction of particles in liquid have been reported for inorganic particles [30, 31] and proteins immobilised on the viewing window of the liquid cell [32].

In the present investigation, we employ LPEM to image protein complexes undergoing Brownian motion. In this way, we exploit the proteins natural rotation in liquid in order to access most of the proteins profiles with the aim of reconstructing their 3D structure using tomographic techniques. We imaged proteins dispersed in phosphate buffer solution (PBS) using two liquid cell holders from DENSsolutions, the Ocean and Stream holders (Figure S1). The imaging setup comprised a JEOL JEM2200 FS TEM equipped with a metal-oxide-semiconductor (CMOS)based direct electron detection camera (Gatan K2 IS) which allows low-dose and high speed imaging with high detective quantum efficiency (DQE) [33]. We chose two different proteins to 
bioRxiv preprint doi: https://doi.org/10.1101/2021.04.30.442083; this version posted April 30, 2021. The copyright holder for this preprint (which was not certified by peer review) is the author/funder, who has granted bioRxiv a license to display the preprint in perpetuity. It is made available under aCC-BY-NC 4.0 International license.

De Pace et al. Imaging protein conformational space in liquid water

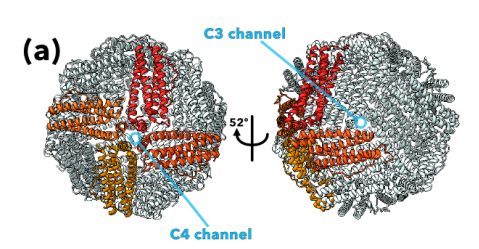

(c)

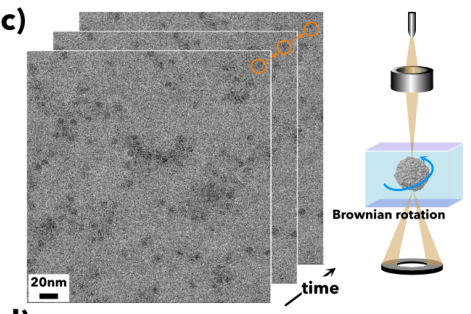

(d)

Figure 1. Description of Brownian tomography and particle analysis. Structure of apoferritin (a) showing both C3 and C4 channels, and archaeal RNA polymerase (RNAP) showing the different domains (b). Schematics of the Brownian tomography (c) and Brownian particle analysis (d) workflows to extract the 3D structure of a protein dispersed in water and undergoing Brownian motion. Reconstructed 3D models of apoferritin via Brownian Tomography and Brownian particle analysis shown at the far right side of (c) and (d) respectively.
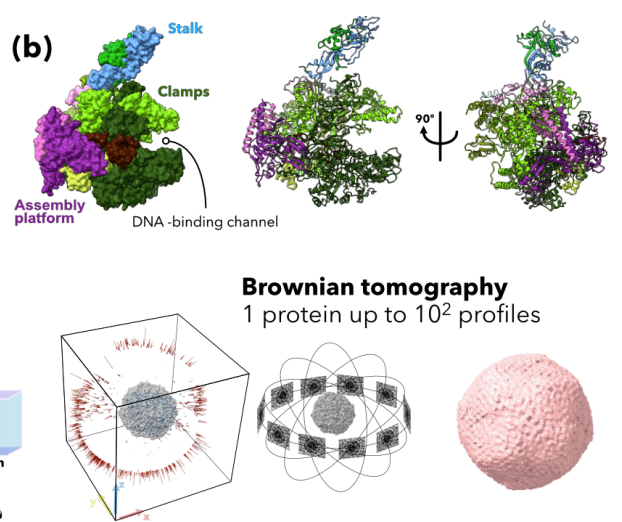

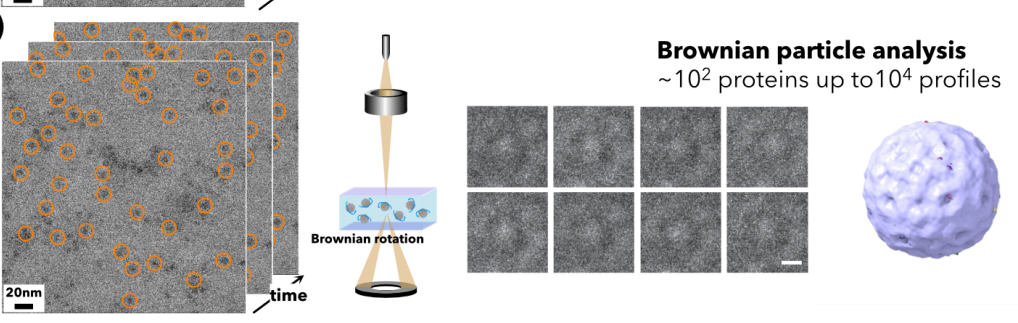

narrower than the $\mathrm{C} 3$ channels, and to a large extent hydrophobic [36].

Double-psi beta barrel (DPBB) RNA polymerases (RNAPs) carry out transcription in all cellular life forms as well as some viruses and bacteriophages [35]. Archaeal and eukaryotic RNA polymerases are closely related in terms of subunit composition, structure, molecular mechanisms, utilisation of basal transcription factors, promoter DNA sequence motifs, and histone-based chromatin templates [36]. As shown in figure $\mathbf{1} \mathbf{b}$, we can identify four prominent structural features of RNAP, the DNA-binding channel, the clamp that closes over the DNAbinding channel and stabilises RNAP-DNA complexes, the assembly platform, and the stalk that interacts with nascent RNA chain and serves as docking point for accessory RNA-processing factors. [36] Both RNAP clamp and stalk are flexible motifs, and their exact conformation is influenced by the binding of general factors (TFE and Spt4/5), and the DNA/RNA scaffold of transcription complexes as RNAP progresses repeatedly through the transcription cycle [36][37, 38].

We imaged apoferritin in liquid phase (Figures S2.a-b) obtaining contrast similar to that afforded by cryogenic fixation (Figure S2.b) under the same imaging conditions. We achieve similar results with RNAP proteins (Figures S2.c-d) and most importantly we can collect a sufficient number of frames maintaining the total electron dose well below the damage lethal dose threshold $<10$ electron per $\AA^{2}$ of cumulative dose, as recognised from cryoEM work [39]. We imaged protein dispersions free to diffuse in water over time, and we propose two approaches to analyse their structure: Brownian tomography (BT) (Figure 1c) and Brownian particle analysis (BPA) (Figure 1d). In BT we select and track a single protein long enough to access most of its profile views which are then aligned and converted into a 3D structure. In BPA, we image a given population of proteins captured in the field of view over time and create a 
bioRxiv preprint doi: https://doi.org/10.1101/2021.04.30.442083; this version posted April 30, 2021. The copyright holder for this preprint (which was not certified by peer review) is the author/funder, who has granted bioRxiv a license to display the preprint in perpetuity. It is made available under aCC-BY-NC 4.0 International license.

data set of different profiles which are sifted and sorted into different 2D classes to reconstruct the relative $3 \mathrm{D}$ structure. Such a process is iterative and involves, firstan alignment and averaging step to create an initial volume that becomes the reference for the next iteration.. This initial model is further refined through an iterative algorithm either unbiased or introducing an initial reference model increasing spatial resolution across iterations [40]. Such a reference model should be accurate enough to improve data refinement but not too accurate in order not to bias the data. Hence, it is common practice to use a low-pass filtered map of a known similar structure. This latter can be either a structure or a substructure obtained by other experimental techniques (e.g. $\mathrm{x}$ ray or NMR), or computationally generated homology or even de-novo models. In Figure S3, we show the electron density (ED) maps for apoferritin generated by means of both BT and BPA using either unbiased refinement or a low-pass filtered ED map calculated from the deposited x-ray apoferritin PDB structure. The generated maps show that templating the refinement improves the resolutions considerably for both reconstruction methods allowing the visualisation of the core-shell structure of apoferritin. However, only the BT maps show the expected octahedral symmetry (Figure S3.a) while the BPA maps show a spherical structure with undistinguishable features (Figure S3.b). Most importantly, the resolution achieved for none of the generated ED maps is sufficient to visualise unique apoferritin structural elements such as C4 or C3 channels. The lack of detail is very likely due to the fact that proteins in liquid at room temperature can explore wider conformational spaces than in frozen vitrified state. Our time resolution $(\sim 100 \mathrm{~ms})$ is not close to the protein rotational correlation time $\tau_{R} \sim 1 \mu \mathrm{s}$ nor the protein internal structure vibrations with correlation times in the order of ns. Whilst protein rotational dynamics being faster than our sampling aid to capture more profiles from one frame to another, we expect our reconstructions independently of the intervals used, to be time-averaged. In this fashion, we anticipate that the LPEM generated reconstructions represent the volume occupied by all the 
bioRxiv preprint doi: https://doi.org/10.1101/2021.04.30.442083; this version posted April 30, 2021. The copyright holder for this preprint (which was not certified by peer review) is the author/funder, who has granted bioRxiv a license to display the preprint in perpetuity. It is made available under aCC-BY-NC 4.0 International license.

(a)
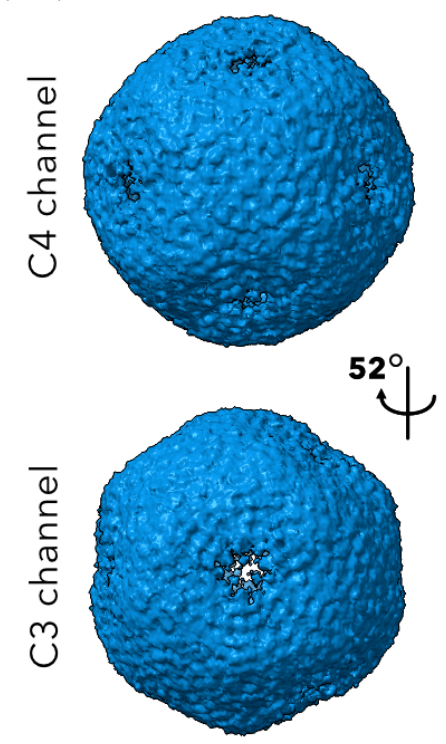

(b)
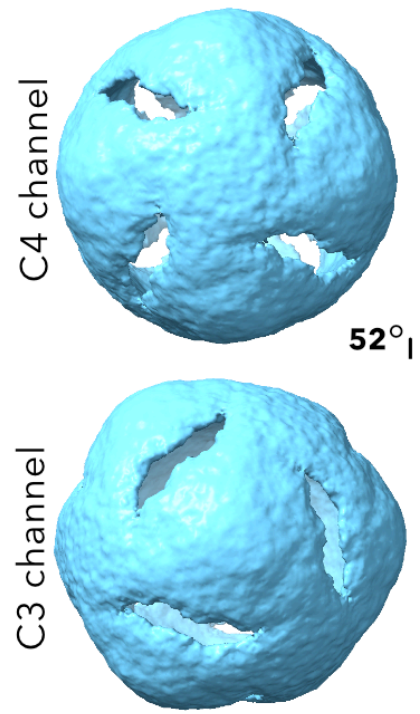

Brownian tomography 1 protein
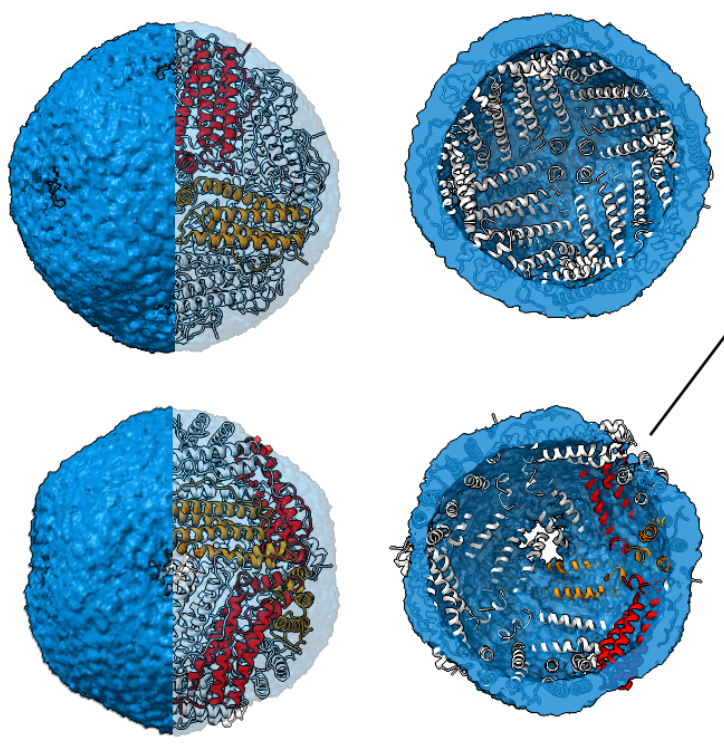

Brownian particle analysis $\sim 10^{2}$ proteins
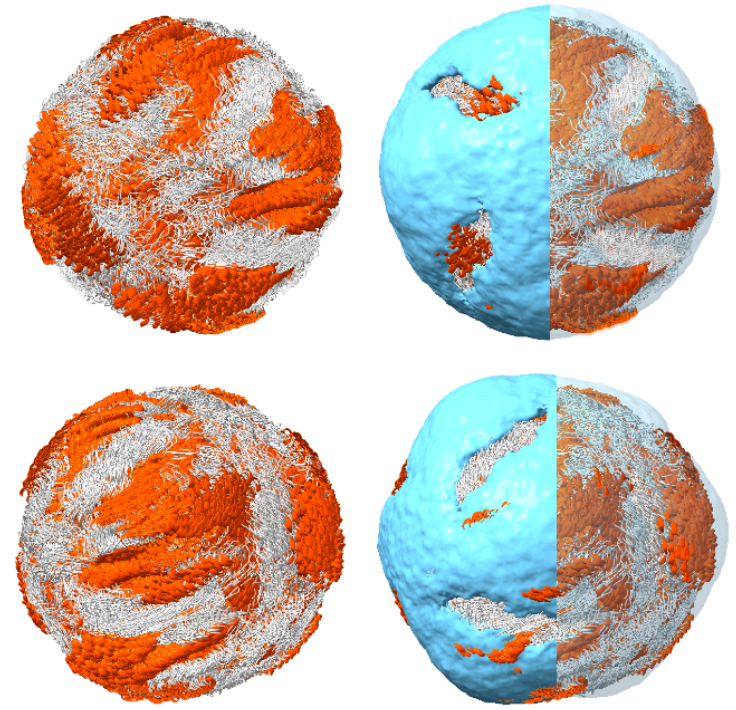
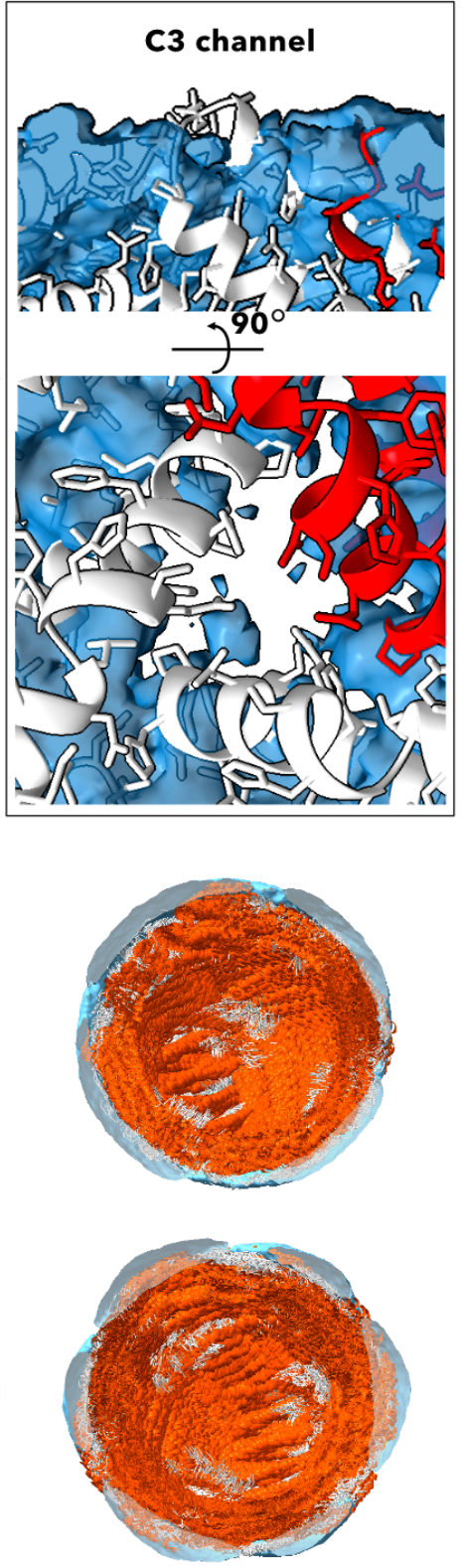

(c)

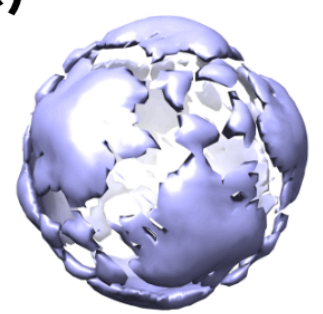

$0-1 \mathrm{~s}$

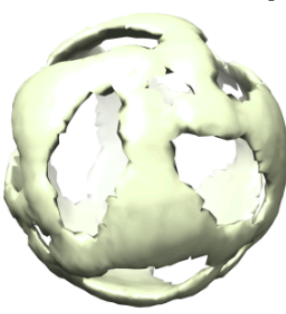

$1-2 \mathrm{~s}$

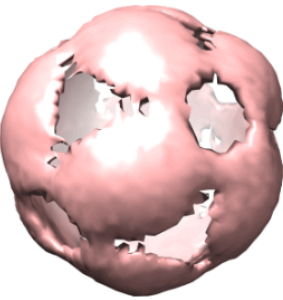

$2-3 s$

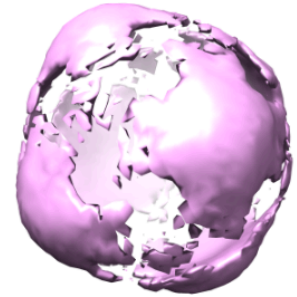

$3-4 \mathrm{~s}$

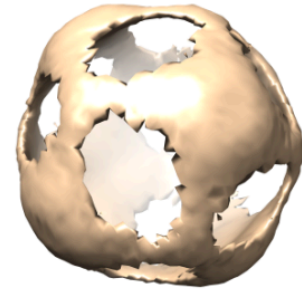

$4-5 s$

Figure 3. Apoferritin structure. Apoferritin brownian tomography (BT) electron density (ED) map generated from LPEM displayed at both C4 and C3 channel orientations as stand alone density (left hand side), as well as overlapped with the apoferritin crystallographic structure both clipped (centre) or as equatorial cross section (right hand side); detailed view of the C3 channel at the far right side (a). Apoferritin brownian particle analysis (BPA) ED map generated from LPEM (light blue) displayed alongside one hundred overlapping configurations from molecular dynamics simulations (a-helixes and coils coloured in orange and white respectively) The BPA ED map is overlapped with MD simulations both clipped or as equatorial cross section at the right and far right side respectively (b). Temporal evolution of the Apoferritin density map reconstructed by BPA. Profiles of 32 particles were extracted from each frame and were split into 10-frame sets of $1 \mathrm{~s}$ long duration, these were then used for separate refinements, generating five different density maps shown here (c). 
bioRxiv preprint doi: https://doi.org/10.1101/2021.04.30.442083; this version posted April 30, 2021. The copyright holder for this preprint (which was not certified by peer review) is the author/funder, who has granted bioRxiv a license to display the preprint in perpetuity. It is made available under aCC-BY-NC 4.0 International license.

protein conformations within the time scale used for imaging.

Multiple 3D density maps in distinct conformational or compositional states can sometimes be obtained $[20,21]$ however these states maps required large number of profiles and adequate classifications. Herein, we leverage long molecular dynamics (MD) simulations of both apoferritin and archaeal RNAP in solution $(150 \mathrm{mM} \mathrm{NaCl}$ ) at room temperature. During long MD simulations the system under investigation explores a conformational ensemble accessible for the starting state at a given temperature. In Figure $\mathbf{2 a}$ we depicted the apoferritin structure showing one unit with sixty overlapped conformations and coloured as a function of the rootmean-square deviation from the reference atomic positions (RMSD) during MD. We also show the whole apoferritin protein with the sixty conformations superimposed and coloured

(a)

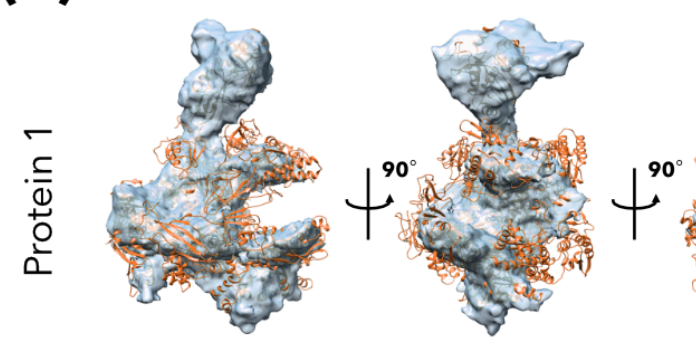

Brownian tomography
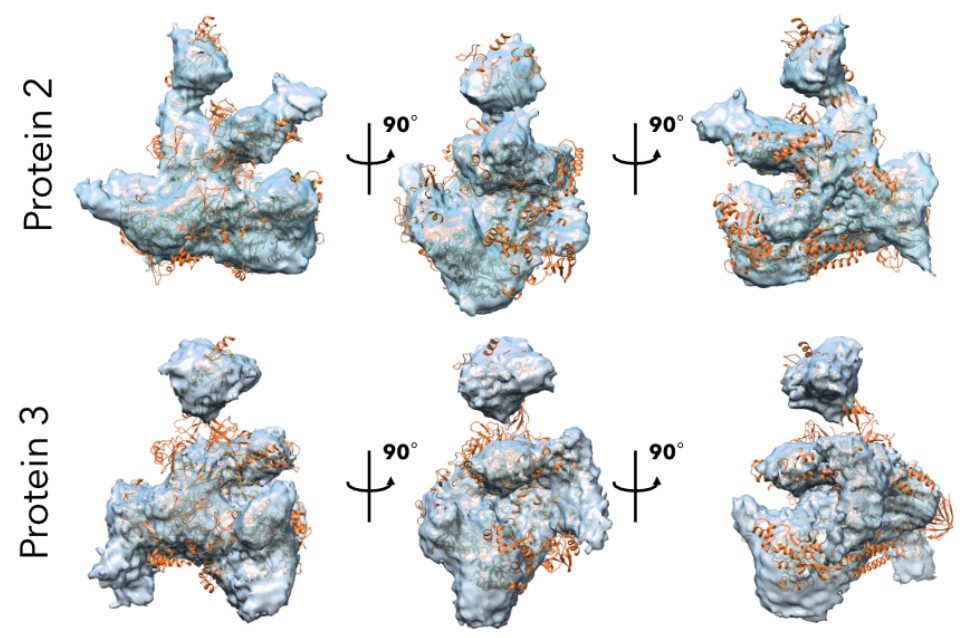

(b)

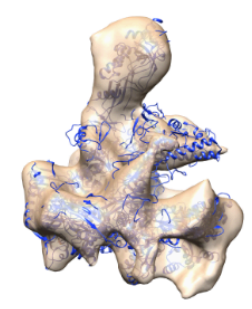

Brownian particle analysis
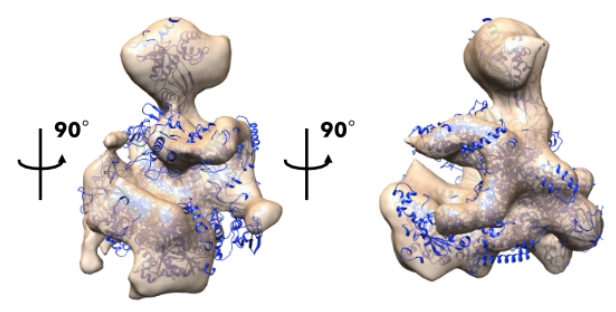

(c)
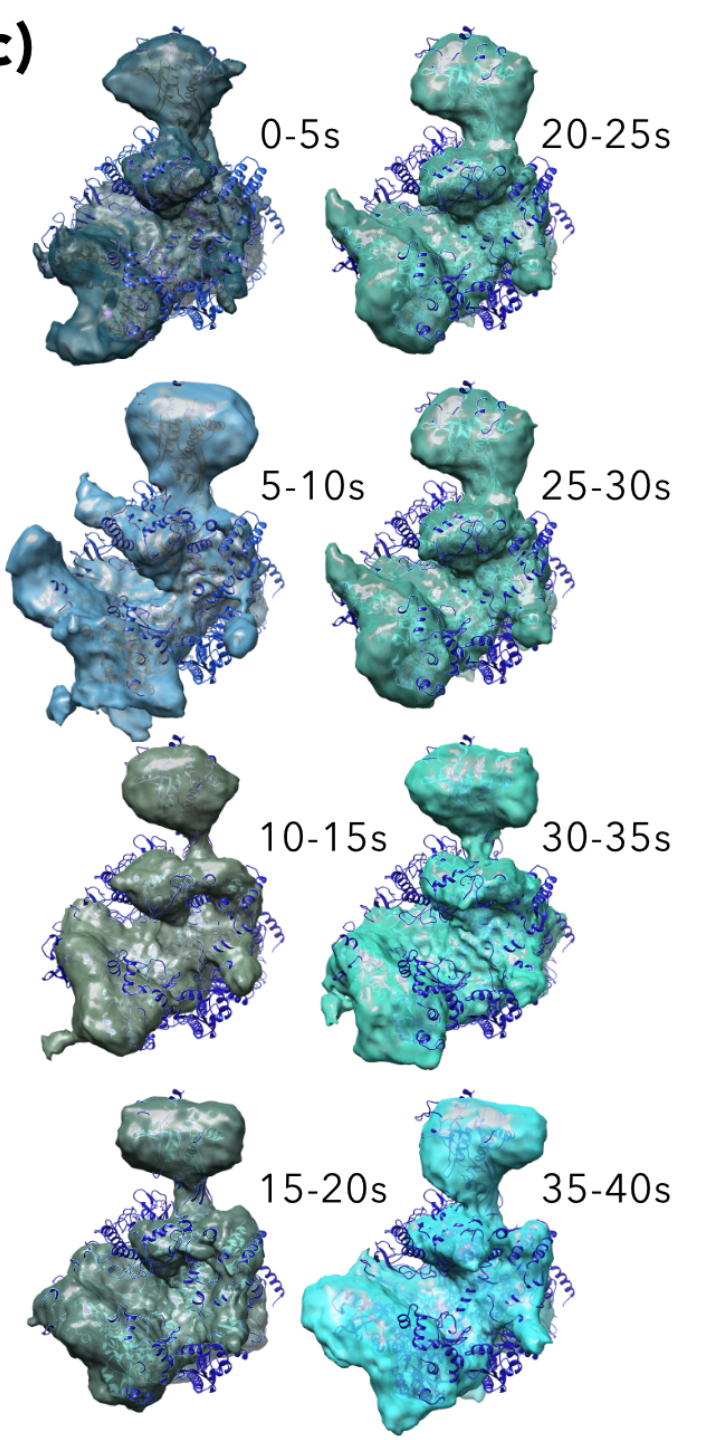

Figure 4. BT and BPA reconstruction of archaeal RNAP. BT electro density (ED) map generated from LPEM employing the dynamical map as refinement model showing three different RNAP proteins at different orientations. The published RNAP structure is overlapped to show correlation (a). BPA ED map generated from 5600 profiles of 14 particles over a 40s (400 frame) time period, with published structure aligned (b). Temporal evolution of the RNAP density map reconstructed by BPA. The set of 5600 profiles was broken up into 50 frame (5s) groups, each with 700 profiles, yielding eight individually refined models (c).

according to its secondary structure, the a-helices and coils in orange and white respectively 
bioRxiv preprint doi: https://doi.org/10.1101/2021.04.30.442083; this version posted April 30, 2021. The copyright holder for this preprint (which was not certified by peer review) is the author/funder, who has granted bioRxiv a license to display the preprint in perpetuity. It is made available under aCC-BY-NC 4.0 International license.

(Figure 2b). We performed a similar analysis for RNAP and we show two orientations of sixty superimposed RMSD coloured conformations in Figure 2c. To shed light on the effect of dynamics on the local structure, we extracted a fourth-dimensional residence time matrix from the all-atom trajectories. For each frame of the trajectory, the system is roto-translated into a reference template (initial molecular dynamics structure). The rotation matrix of the system snapshot onto the template is calculated via a least-square rigid motion transformation using single value decomposition. This algorithm finds the best-fitting rigid transformation that aligns two sets of corresponding points. Then an occupation fourth-dimensional matrix is calculated and exported as a volumetric map. The resulting maps for apoferritin and RNAP are displayed in Figures $\mathbf{2} \mathbf{d}$ and $\mathbf{2 e}$ respectively for different atom residency times showing dynamical information at different time-scales. The MD simulations show a relative rigid structure for apoferritin with maximum RMSD of $1.5 \AA$. The RNAP structure is considerably more flexible with several units within the stalk and the DNA binding cleft reaching RMSD of $5.4 \AA$. The 'dynamical maps' (Figures 2d-e) calculated from molecular dynamics encodes thermal fluctuations and the accessible conformational micro-states of the structure at the given temperature. Importantly, the conformational dynamics of the RNAP stalk and clamp are in good agreement with structural changes that have been partially characterised by comparing different molecular structures determined by cryoEM or crystallography, or by using single-molecule FRET of double-labelled RNAP in solution [38][41]. The different levels of the map i.e. from left to right correspond to the dynamical information at different time-scales and associated structural features. In Figure S4 we show the difference between a low-pass filtered map , we refer to as 'static map', generated from x-ray of the all-atom structure for the archaeal RNAP polymerase and its 'dynamical map'. It is interesting to note that the correlation between the two maps increases up to a certain spatial resolution, without being a perfect match, see Table $\mathbf{S 1}$.

In Figure 3, we show the reconstructed ED map from both BT and BPA methods for apoferritin using the 'dynamical map' as initial model for the refinement. As shown in Figure 3a, the resolution is considerably improved when employing the BT method, as opposed to BPA, to generate the maps as both the $\mathrm{C} 3$ and $\mathrm{C} 4$ channels become detectable in the generated BT ED map. The C3 appears as a hole in the ED map (Figure 3a) indicating that the local density is the same as bulk water while the C4 appears to be solid in accordance with the channel reported polarity. The C3 pore is notably not visible in the input dynamical map and therefore cannot be a result of model bias. Interestingly, the C3 pore feature is critical to define our spatial resolution; indeed, the biological features suggest an ED map with $9 \AA$ resolution.

As for the BPA ED maps, shown in Figure $\mathbf{3} \mathbf{b}$, the results are rather different; here, the reconstructions are the result of averaging thousands of profiles across several proteins, precisely 2340 profiles of 32 ferritin proteins, and 5600 profiles of 14 RNAP particles. Thus, the reconstructions obtained from BPA represent the conformational space conserved across the different proteins. Interestingly the BPA ED map density matches with close correlation the secondary structure distribution of the proteins. In this fashion the densest areas in the BPA ED map corresponds to the areas where the conformation is mostly an a-helix arrangement, while the lowest density corresponds to the areas with random coil arrangements, depicted in orange and white respectively in Figure $\mathbf{3 b}$. BPA reconstructions can also be performed from a smaller data set and the video can be thus broken down into periods of $1 \mathrm{~s}$. Profiles of 32 particles were extracted from each frame generating 468 total profiles and were split into 10 frames (1s) sets. The profiles contained in each $1 \mathrm{~s}$ set were then used for separate refinements, generating five different sequential density maps over 5 seconds, as shown in Figure 3c. While these maps do not show notable differences from the cumulative map we can grasp some fluctuations between the different secondary arrangements of the protein. 
bioRxiv preprint doi: https://doi.org/10.1101/2021.04.30.442083; this version posted April 30, 2021. The copyright holder for this preprint (which was not certified by peer review) is the author/funder, who has granted bioRxiv a license to display the preprint in perpetuity. It is made available under aCC-BY-NC 4.0 International license.

De Pace et al.

Imaging protein conformational space in liquid water

The symmetrical nature of apoferritin is advantageous for introducing our methodology, however the real impact of the dynamical analysis can be better illustrated when applying it to an asymmetrical protein such as as archaeal RNAP. In Figure 4a, we show the reconstructed BT ED maps for three different RNAP proteins followed during the video along frames, using the 'dynamical map' as initial model. All three particles yield different reconstructions, showing effectively different conformations of the RNAP stalk and clamp, the two most flexible sections. Furthermore, BPA, yields an average reconstruction (Figure $\mathbf{4 b}$ ) that smooth the conformational information encoded in the experimental data, yet the structure is not different from the single BT ED maps suggesting that the defying RNAP features are conserved across long time scales. We broke down the BPA profiles into smaller cohorts each representing a 5 s long period, and the relative ED maps are shown in Figure $\mathbf{4 c}$ as well as morphed together in video S1. Figure 4c shows the fluctuations of the main RNAP features with the stalk exploring a large volume and the DNA binding channel expanding and contracting. This structural evolution demonstrates that while the different parts of the protein fluctuate around the structure, our technique can capture their dynamics over 40 s periods.

In conclusion, we report a completely new way to image proteins in liquid phase exploiting their natural brownian dynamics with the aim of accessing the proteins' conformational repertoire. We show that a single protein particle can be followed using the so called Brownian tomography (BT) method, where we can reconstruct independently every particle, losing 'spatial resolution' due to the fact that single reconstructions are made with less frames, hence, profiles. Nevertheless, the loss of spatial resolution when employing the BT method is compensated by the access to dynamical resolution. We also showed that by combining single particle analysis with brownian dynamics, the so-called Brownian Particle Analysis (BPA), we can access more profiles than when using BT; yet, these profiles are shared across several protein units. Hence, the resulting structure is the average conformational space of the investigated proteins across several micro-states. Most importantly, every particle will evolve independently, stochastically, following a Brownian dynamics as well as being free to explore different conformational arrangements. Imaging proteins in liquid state allows us to use Brownian dynamics to capture and assess the different sides of the protein in a fast manner and probe its conformational dynamics. Finally, we can observe that despite the fact that our reconstruction do not offer atom level information, we do image the entire particle and we have access to structural information using BT coupled with molecular dynamics. Both inter- and intra- particle dynamics are lost by the need to vitrify the water in cryo-EM or crystallise the proteins in x-ray crystallography losing important structural information associated with molecular dynamics. Moreover, it is important to notice that the best cryo-EM reconstructions are based on $10^{6}$ independent particles across as a large number of proteins. Herein, we limit the protein number to several hundreds in BPA dictated by the number of particles in the field of view, and to one in BT with $10^{3}$ and $10^{2}$ number of profiles respectively. These number of profiles arethree and four orders of magnitudes less than current cryo-EM approaches, yet they achieve spatial resolution of about six times worst than that achieved by cryo-EM. While we are years away from filling such a resolution gap, we believe that our LPEM BT and BPA approach can be very well combined with cryo-EM and simulations to access the 4th dimension in structural biology accessing important dynamic information so far out of reach. 
bioRxiv preprint doi: https://doi.org/10.1101/2021.04.30.442083; this version posted April 30, 2021. The copyright holder for this preprint (which was not certified by peer review) is the author/funder, who has granted bioRxiv a license to display the preprint in perpetuity. It is made available under aCC-BY-NC 4.0 International license.

De Pace et al.

Imaging protein conformational space in liquid water

\section{Acknowledgements}

We acknowledge the EPSRC (grant EP/N010906/1), Jeol UK and DENSsolutions for sponsoring part of this work, LRP salary as well as GM and CDP scholarship. GB acknowledges the EPSRC for funding part of his salary via an Established Career Fellowship (EP/N026322/1) and the ERC (CheSSTag 769798) via a consolidator award F.L.G. acknowledges funding from EPSCR (Grants EP/P022138/1, EP/P011306/1) and European Commission H2020 Human Brain Project CDP 6. HEC-BioSim (EP/R029407/1), PRACE (BSC, Project BCV-2019-3-0010 and CSCS ProjectS847), CSCS (Project 86), and the Leibniz Supercomputing Center (SuperMUC, Project pr74su) are acknowledged for their generous allocation of supercomputer time. G.B. and S.A.G. acknowledge the Spanish Supercomputer Network, RES, for their allocation of HPC resources, project BCV-2020-3-0009 (Tirant UV).

\section{Experimental methods}

Protein sources and production. RNAP polymerase was prepared from Sulfolobus acidocaldarius cells using the method reported by Blombach et al. [42]. Equine spleen apoferritin was purchased from Merck (previously Sigma-Aldrich) and diluted with phosphate buffer solution (PBS) at a concentration of $2 \mathrm{mg} / \mathrm{ml}$.

Liquid holders methodology. Two liquid holders were used for the experiments, the OCEAN and STREAM holders, both manufactured by DENSsolutions. The first generation Ocean holder was employed for the experiments on apoferritin. The last generation Stream holder was employed for the experiments on RNA polymerase. The use of the different holders does not influence the results of the BPA and BT techniques. The most important variable is always the liquid thickness, which will directly affect the electrons transmitted through the specimen, hence specimen contrast and ultimately the resolution of the acquired images and the magnification that can be used.

For the OCEAN holder preparation, the ferritin in solution was sandwiched in a liquid cell formed by two chips made of silicon nitride (SixNy), with $50 \mathrm{~nm}$ thick rectangular observation windows at the centre measuring $20 \mathrm{~mm} \times 200 \mathrm{~mm}$. Silicon nitride prevents the solution from leaking from the closed cell and allows the passage electrons through the sample as it is electron transparent. The liquid cell is comprised of a spacer-chip placed at the bottom and a spacer-less chip placed at the top. $200 \mathrm{~nm}$ spacer chips were used for the reported investigation. The SiN chips were rinsed in HPLC-graded acetone followed by isopropanol for five minutes each, to eliminate their protective layer made of poly(methyl methacrylate) (PMMA). Then, the chips were plasma cleaned for thirteen min to increase their hydrophilicity. Soon after, the chip with the $200 \mathrm{~nm}$ spacer was fitted at the bottom of the liquid cell and $1.5 \mu \mathrm{L}$ of ferritin solution was deposited onto the observation window of the chip. It was important to not allow the ferritin solution dry at this stage as the film thickness generated by dried ferritin solution cannot be easily controlled and impedes good imaging conditions. The chip without spacer was then positioned on top of the liquid layer closing the liquid cell. The observing windows at the top and bottom chips were placed in a perpendicular configuration. The liquid holder was sealed, and $300 \mu \mathrm{L}$ of the ferritin solution at $2 \mathrm{mg} / \mathrm{mL}$ was flushed in at $20 \mu \mathrm{L} / \mathrm{min}$ with a peristaltic pump. A volume of $300 \mu \mathrm{L}$ of solution ensured that the holder tubing system and cell were filled with 
bioRxiv preprint doi: https://doi.org/10.1101/2021.04.30.442083; this version posted April 30, 2021. The copyright holder for this preprint (which was not certified by peer review) is the author/funder, who has granted bioRxiv a license to display the preprint in perpetuity. It is made available under aCC-BY-NC 4.0 International license.

De Pace et al.

Imaging protein conformational space in liquid water

ferritin solution. Although the liquid thickness is dictated by the spacer used in the liquid cell, the observation windows of the chips tend to experience some bulging, mainly at their centre point. This bulging effect is due to the differential pressure encountered by the holder once it is inserted into the vacuum of the microscope. The bulging phenomenon of the windows consequently adds some en.xtra thickness to the observation chamber. The bulging effect is at minimum however at the corners of the rectangular windows. Thus, ferritin imaging was performed at the areas close to the corners of the SixNy window.

For the STREAM holder preparation, the chips did not require cleaning with organic solvent as they were supplied without protective layer. The chips were plasma cleaned to increase their hydrophobilicity and hence wettability of the protein solution. The observing windows of the top and bottom chips were aligned manually using an optical microscope and in a perpendicular configuration. As with the Ocean, the top and bottom chips were separated by a $200 \mathrm{~nm}$ spacer. The liquid holder was sealed by slowly increasing the torque of the screws to a maximum of $1 \mathrm{cN}$ while checking the windows were aligned. Then, $1 \mathrm{mg} / \mathrm{mL}$ of RNAP solution was used to fill the tubing system. A volume of $300 \mu \mathrm{L}$ of RNAP solution was flushed in the sealed holder at $1 \mu \mathrm{L} / \mathrm{min}$ with a liquid nitrogen pump.

In both liquid holders, we stopped the pumps after collecting the respective sample solution from the outlet tube (Fig.S1). In the case of the STREAM holder the liquid thickness was reduced by applying a negative pressure in the outlet tube, effectively extracting some specimen sandwiched between the observing windows. The negative pressure did also help to reduce the bulging of the observing windows. A reduced liquid thickness and window bulging allowed to acquire images of RNAp at 30Kx magnification with good contrast and SNR. Then, we waited five minutes in order to guarantee that convection effects from the flowing process were not affecting the Brownian movement of the samples in solution. The inlet and outlet tubes of the pumps were sealed to ensure a closed liquid circuit.

The liquid holders were then introduced into the microscope. Imaging was performed with the holder in static conditions i.e. the pumps were stopped during imaging. Fluid dynamics simulations were performed on the OCEAN liquid holder and are reported in the SI section addressing Fluid dynamics simulation.

Imaging methodology.The experiments were performed using a JEOL JEM-2200FS TEM microscope equipped with a field emission gun (FEG) at $200 \mathrm{kV}$, and an in-column Omega filter. The camera used was the direct detection device (DDD) in-situ K2-IS camera from Gatan. The ultra-high sensitivity of the K2 allows low-dose imaging modes limiting considerably electron dose damage and facilitating high spatial ( $3838 \times 3710$ pixels) and temporal (up to $1600 \mathrm{fps}$ in in-situ mode) resolution. The microscope was used in transmission electron microscopy mode. In order to limit the beam dose on the specimen, images were collected at the minimum spot size (5) with a small condenser lens aperture (CLA 2). The K2 can be used in two recording modes, linear and counted. The former is fast, but it generates the output image by capturing the integrated signal from each pixel, in a similar way to a standard charge coupled device (CCD). Counted mode processes the image and assigns one count to the pixel or sub pixel of the landing site of that electron For our investigations dose fractionation videos were recorded in counted mode. Further details on the quality of the videos are provided in the Video analysis section. The apoferritin video used was a single $5 \mathrm{~s}$ dose fractionation video at $10 \mathrm{fps}$ resulting in a total of 50 frames. The electron flux of this video was circa 0.9 e-/A2 per frame and a total cumulative electron dose of $4.5 \mathrm{e}-/ \mathrm{A}^{2}$. The magnification used for apoferritin was $20 \mathrm{Kx}$. The RNAP video used was composed by 400 frames, generated from four 10 s dose fractionation videos at 10fps under identical imaging conditions The electron flux of these videos were 
bioRxiv preprint doi: https://doi.org/10.1101/2021.04.30.442083; this version posted April 30, 2021. The copyright holder for this preprint (which was not certified by peer review) is the author/funder, who has granted bioRxiv a license to display the preprint in perpetuity. It is made available under aCC-BY-NC 4.0 International license.

De Pace et al.

Imaging protein conformational space in liquid water

$0.038 \mathrm{e}-/ \mathrm{A}^{2}$ per frame, giving a total cumulative dose of $15.2 \mathrm{e}-/ \AA^{2}$. The magnification used for RNAp was $30 \mathrm{Kx}$. Every image was recorded in the format of 4-byte grayscale and required the full size of the detector.

MD. We simulate apoferritin starting from the biological assembly of a $1.43 \AA$ resolution $x$-ray crystal structure (PDB-id: 6MSX) containing $\mathrm{Cd}^{2+}$. Only the positions of the protein coordinated $\mathrm{Cd}^{2+}$ atoms were retained and simulated as $\mathrm{Fe}^{2+}$. The protein complex presented no mutations or structural gaps; therefore, it was protonated at $\mathrm{pH} 7.4$ and solvated $(150 \mathrm{mM} \mathrm{NaCl})$ using a TIP3P[43] water model and Charmm36m[44] protein and ions force field. The final simulated system consisted of 336806 atoms, resulting in a truncated octahedron simulation cell of $16.14 \mathrm{~nm} \times 15.21 \mathrm{~nm} \times 13.17 \mathrm{~nm}(5.37,-5.37,7.6)$. All simulations were performed with Gromacs v2019.2 [45] with a 2fs integration step. We performed 2000 steps of minimization (steepest descent algorithm), followed by 5000 steps of isotropic NPT at 300K, using the velocity-rescaling thermostat[46] and Parrinello-Rahman barostat [47]. After 50000 steps of NVT the system was fully equilibrated and ready for production, which was performed in the NVT ensemble for 1 microsecond.

The simulation of archaeal RNA polymerase was started from the cryo-EM structure of the apoRNA polymerase (manuscript submitted at the time of submission of the present work). PDBidX. Missing residues and loops were modelled using MODELLER[48]. The protein complex ,including the structural $\mathrm{Zn}^{2+}, \mathrm{Mg}^{2+}$, was protonated at $\mathrm{pH} 7.4$ and solvated $(150 \mathrm{mM}$ $\mathrm{NaCl}$ ) using a TIP3P[43] water model and Charmm36m[44]. The final simulated system consisted of 539642 atoms, resulting in a truncated octahedron simulation cell of $18.94 \mathrm{~nm} \times 17.86 \mathrm{~nm} \times$ $15.47 \mathrm{~nm}(6.31,-6.31,8.93)$. The same equilibration protocol mentioned above was followed and 1 microsecond of NVT production was generated.

Dynamical map calculation. We calculated a fourth-dimensional residence time matrix for both systems, apoferritin and RNAp, from their all-atom MD trajectories. For each frame of the trajectory, the system is roto-translated into a template (initial molecular dynamics structure). The rotation matrix of the system snapshot onto the template is calculated using a least-squares rigid motion transformation using single value decomposition. Then an occupation fourthdimensional matrix is calculated and exported as a volumetric map.

Reconstruction methodology. The individual frames of the dose-fractionation videos were exported and processed individually. The apoferritin frames were first denoised using a noise2void neural network [49], with a network trained on sets of 200 similar apoferritin video frames, this procedure did not prove beneficial for RNAP. . Reconstructions were performed using Relion 2.0 methods [50, 51] within the Scipion framework [52]. For Brownian tomography, the particles were tracked and picked manually across the consecutive frames to render 400 profiles per particle for RNAP, and 50 profiles per particle for apoferritin. For Brownian particle analysis in RNAP all 400 profiles of 14 particles were combined to render a total of 5600 effective profiles. These profiles were split into groups of 700 particles for each of the $5 \mathrm{~s}$ timeresolved reconstructions. For apoferritin, many particles within each frame were manually picked, rendering a total of 2340 particles. The time-resolved structures for apoferritin used profiles of 32 particles across the 10 frame (1s) intervals, making 320 profiles per reconstruction. The particle sets were then used with "relion_refine" to refine models of the respective protein, with initial models originating either from atomic models low-pass filtered to $60 \AA$ or from dynamic models representing the residence time of atoms from a $1 \mu$ s long simulation of the proteins. Octahedral symmetry was applied for ferritin refinement. 
bioRxiv preprint doi: https://doi.org/10.1101/2021.04.30.442083; this version posted April 30, 2021. The copyright holder for this preprint (which was not certified by peer review) is the author/funder, who has granted bioRxiv a license to display the preprint in perpetuity. It is made available under aCC-BY-NC 4.0 International license.

\section{References}

1. Rodriguez-Arco, L., et al., Molecular bionics - engineering biomaterials at the molecular level using biological principles. Biomaterials, 2019. 192: p. 26-50.

2. McDowall, A.W., et al., Electron microscopy of frozen hydrated sections of vitreous ice and vitrified biological samples. J Microsc, 1983. 131(Pt 1): p. 1-9.

3. Bai, X.C., G. McMullan, and S.H. Scheres, How cryo-EM is revolutionizing structural biology. Trends Biochem Sci, 2015. 40(1): p. 49-57.

4. Cheng, Y., R.M. Glaeser, and E. Nogales, How Cryo-EM Became so Hot. Cell, 2017. 171(6): p. 1229-1231.

5. Dubochet, J., On the Development of Electron Cryo-Microscopy (Nobel Lecture). Angew Chem Int Ed Engl, 2018. 57(34): p. 10842-10846.

6. Frank, J., Single-Particle Reconstruction of Biological Molecules-Story in a Sample (Nobel Lecture). Angew Chem Int Ed Engl, 2018. 57(34): p. 10826-10841.

7. Henderson, R., From Electron Crystallography to Single Particle CryoEM (Nobel Lecture). Angew Chem Int Ed Engl, 2018. 57(34): p. 10804-10825.

8. Jonic, S., C.O. Sorzano, and N. Boisset, Comparison of single-particle analysis and electron tomography approaches: an overview. J Microsc, 2008. 232(3): p. 562-79.

9. Orlova, E.V. and H.R. Saibil, Structural analysis of macromolecular assemblies by electron microscopy. Chem Rev, 2011. 111(12): p. 7710-48.

10. Frank, J., A. Verschoor, and M. Boublik, Computer averaging of electron micrographs of 40S ribosomal subunits. Science, 1981. 214(4527): p. 1353-5.

11. Sorzano, C.O.S., et al., A Survey of the Use of Iterative Reconstruction Algorithms in Electron Microscopy. Biomed Res Int, 2017. 2017: p. 6482567.

12. Henderson, R., Realizing the potential of electron cryo-microscopy. Q Rev Biophys, 2004. 37(1): p. 3-13.

13. Merk, A., et al., Breaking Cryo-EM Resolution Barriers to Facilitate Drug Discovery. Cell, 2016. 165(7): p. 1698-1707.

14. Nakane, T., et al., Single-particle cryo-EM at atomic resolution. Nature, 2020. 587(7832): p. 152-156.

15. Naydenova, K., P. Jia, and C.J. Russo, Cryo-EM with sub-1 A specimen movement. Science, 2020. 370(6513): p. 223-226.

16. Yip, K.M., et al., Atomic-resolution protein structure determination by cryo-EM. Nature, 2020. 587(7832): p. 157-161.

17. Zewail, A.H., Four-dimensional electron microscopy. Science, 2010. 328(5975): p. 187-93.

18. Saibil, H.R., Conformational changes studied by cryo-electron microscopy. Nat Struct Biol, 2000. 7(9): p. 711-4.

19. Frank, J., Time-resolved cryo-electron microscopy: Recent progress. J Struct Biol, 2017. 200(3): p. 303-306.

20. Schoehn, G., et al., Three conformations of an archaeal chaperonin, TF55 from Sulfolobus shibatae. J Mol Biol, 2000. 296(3): p. 813-9.

21. Murphy, B.J., et al., Rotary substates of mitochondrial ATP synthase reveal the basis of flexible F1-Fo coupling. Science, 2019. 364(6446).

22. Huang, C. and C.G. Kalodimos, Structures of Large Protein Complexes Determined by Nuclear Magnetic Resonance Spectroscopy. Annu Rev Biophys, 2017. 46: p. 317-336. 
bioRxiv preprint doi: https://doi.org/10.1101/2021.04.30.442083; this version posted April 30, 2021. The copyright holder for this preprint (which was not certified by peer review) is the author/funder, who has granted bioRxiv a license to display the preprint in perpetuity. It is made available under aCC-BY-NC 4.0 International license.

De Pace et al.

Imaging protein conformational space in liquid water

23. de Jonge, N. and F.M. Ross, Electron microscopy of specimens in liquid. Nat Nanotechnol, 2011. 6(11): p. 695-704.

24. Wu, H., et al., Liquid-Phase Electron Microscopy for Soft Matter Science and Biology. Adv Mater, 2020. 32(25): p. e2001582.

25. Radisic, A., et al., Quantifying electrochemical nucleation and growth of nanoscale clusters using real-time kinetic data. Nano Lett, 2006. 6(2): p. 238-42.

26. Williamson, M.J., et al., Dynamic microscopy of nanoscale cluster growth at the solidliquid interface. Nat Mater, 2003. 2(8): p. 532-6.

27. Zheng, $\mathrm{H}_{\text {., }}$ et al., Observation of single colloidal platinum nanocrystal growth trajectories. Science, 2009. 324(5932): p. 1309-12.

28. Thiberge, S., et al., Scanning electron microscopy of cells and tissues under fully hydrated conditions. Proc Natl Acad Sci U S A, 2004. 101(10): p. 3346-51.

29. Peckys, D.B., et al., Nanoscale imaging of whole cells using a liquid enclosure and a scanning transmission electron microscope. PLoS One, 2009. 4(12): p. e8214.

30. Park, J., et al., Nanoparticle imaging. 3D structure of individual nanocrystals in solution by electron microscopy. Science, 2015. 349(6245): p. 290-5.

31. Kim, B.H., et al., Critical differences in 3D atomic structure of individual ligand-protected nanocrystals in solution. Science, 2020. 368(6486): p. 60-67.

32. Cameron Varano, A., et al., Visualizing virus particle mobility in liquid at the nanoscale. Chem Commun (Camb), 2015. 51(90): p. 16176-9.

33. McMullan, G., et al., Detective quantum efficiency of electron area detectors in electron microscopy. Ultramicroscopy, 2009. 109(9): p. 1126-43.

34. Theil, E.C., Ferritin: structure, gene regulation, and cellular function in animals, plants, and microorganisms. Annu Rev Biochem, 1987. 56: p. 289-315.

35. Werner, F. and D. Grohmann, Evolution of multisubunit RNA polymerases in the three domains of life. Nature Reviews Microbiology, 2011. 9(2): p. 85-98.

36. Blombach, F., et al., Key Concepts and Challenges in Archaeal Transcription. J Mol Biol, 2019. 431(20): p. 4184-4201.

37. Grohmann, D., et al., The initiation factor TFE and the elongation factor Spt4/5 compete for the RNAP clamp during transcription initiation and elongation. Molecular cell, 2011. 43(2): p. 263-274.

38. Schulz, S., et al., TFE and Spt4/5 open and close the RNA polymerase clamp during the transcription cycle. Proceedings of the National Academy of Sciences, 2016. 113(13): p. E1816E1825.

39. Frank, J., Single-particle reconstruction of biological macromolecules in electron microscopy-30 years. Quarterly reviews of biophysics, 2009. 42(3): p. 139-158.

40. Leigh, K.E., et al., Subtomogram averaging from cryo-electron tomograms, in ThreeDimensional Electron Microscopy. 2019. p. 217-259.

41. Duchi, D., et al., The RNA polymerase clamp interconverts dynamically among three states and is stabilized in a partly closed state by ppGpp. Nucleic acids research, 2018. 46(14): p. 7284-7295.

42. Blombach, F., et al., Archaeal TFEa/ $\beta$ is a hybrid of TFIIE and the RNA polymerase III subcomplex hRPC62/39. Elife, 2015. 4: p. e08378.

43. Jorgensen, W.L., et al., Comparison of simple potential functions for simulating liquid water. The Journal of Chemical Physics, 1983. 79(2): p. 926-935.

44. Huang, J., et al., CHARMM36m: an improved force field for folded and intrinsically disordered proteins. Nat Methods, 2017. 14(1): p. 71-73. 
bioRxiv preprint doi: https://doi org/10.1101/2021.04.30.442083; this version posted April 30, 2021. The copyright holder for this preprint (which was not certified by peer review) is the author/funder, who has granted bioRxiv a license to display the preprint in perpetuity. It is made available under aCC-BY-NC 4.0 International license.

45. Abraham, M.J., et al., GROMACS: High performance molecular simulations through multi-level parallelism from laptops to supercomputers. SoftwareX, 2015. 1-2: p. 19-25.

46. Bussi, G., D. Donadio, and M. Parrinello, Canonical sampling through velocity rescaling. J Chem Phys, 2007. 126(1): p. 014101.

47. Rahman, M.P.a.A., Polimorphic transitions in single crystals: A new molecular dynamics method. Journal of Applied Physics, 1981. 52: p. 7182.

48. András Fiser, R.K.G.D., and Andrej Šali, Modeling loops in protein structures. Protein Science, 2000. 9: p. 1753-1773.

49. Krull, A., T.-O. Buchholz, and F. Jug. Noise2void-learning denoising from single noisy images. in Proceedings of the IEEE/CVF Conference on Computer Vision and Pattern Recognition. 2019.

50. Scheres, S.H., A Bayesian view on cryo-EM structure determination. Journal of molecular biology, 2012. 415(2): p. 406-418.

51. Faster to a structure with RELION-2. Nature Methods, 2017. 14(1): p. 12-12.

52. de la Rosa-Trevín, J.M., et al., Scipion: A software framework toward integration, reproducibility and validation in 3D electron microscopy. Journal of Structural Biology, 2016. 195(1): p. 93-99.

53. Dubochet, J., The physics of rapid cooling and its implications for cryoimmobilization of cells. Methods Cell Biol, 2007. 79: p. 7-21.

54. Koga, K., H. Tanaka, and X.C. Zeng, First-order transition in confined water between highdensity liquid and low-density amorphous phases. Nature, 2000. 408(6812): p. 564-7.

\section{Supporting information}

Fluid dynamics simulation.Section Liquid cell preparation and assembly shows how de manding this technique can be, and it is not surprising that the first attempts to image samples 
bioRxiv preprint doi: https://doi.org/10.1101/2021.04.30.442083; this version posted April 30, 2021. The copyright holder for this preprint (which was not certified by peer review) is the author/funder, who has granted bioRxiv a license to display the preprint in perpetuity. It is made available under aCC-BY-NC 4.0 International license.

in liquid state failed due the high complexity of the system. Therefore, a fluid dynamics simulation was performed by using COMSOL Multiphysics in order to understand the functioning of 533 the liquid cell in "in-flow" conditions and obtain the best performance from the imaging process.The liquid holder was modelled in COMSOL using the actual dimensions of the device, the values of which will not be reported in this paper so as not to violate the confidentiality agreement signed between the authors and the manufacturing company. However, the simplified geom etry of the holder is shown in Fig.S1a. The tip of the holder is flower-shaped and is connected to two in plane parallel pipes, an inlet and outlet pipe for flowing in and out of the solution respectively. The holder hosts on the inside two SiN chips separated by a variable gap, creating a microfluidic channel to enable inflow analysis and keep the sample hydrated. The bulging effect on the observation windows occurring when imaging the sample and mentioned in section Liquid cell preparation and assembly of SI has been excluded from the simulation. This is because the simulation has been performed at atmospheric pressure conditions, i.e. when the sample is flowed in the liquid holder outside the microscope. Thus, the windows are treated as flat, rigid surfaces trapping the solution on the inside. Input and output ports were set to the end of the pipes, guaranteeing good fluid circulation. At the beginning of the simulation the chamber was modelled as empty, both chips were removed, and an uncompressible Newto- nian fluid was pumped in with an initial velocity of $5 \neg \mu \mathrm{L} / \mathrm{min}$. The analysis was performed at steady state, imposing laminar flow, planar symmetry and no slip condition on the walls of the holder. The velocity of the fluid in these conditions was analyzed and the results are reported in Fig. S1 b. This first preliminary simulation was mainly performed to validate the goodness of the model, and especially to analyze the trajectory of the flow. The first simulation confirmed that the fluid linearly went from the inlet to the outlet pipes, slowly expanding in the whole volume of the chamber. The results showed that the trajectory of the injected particles were a combination of both convection and Brownian motion experienced by nanoparticles in liquid. Then the complexity of the system was increased by adding the two chips inside the flower-shaped tip, separated by a $200 \mathrm{~nm}$ spacer. The inclusion of the chips significantly influenced the liquid flow inside the chamber, modifying the liquid trajectory and narrowing it down to the small microfluidic channel between the chips. Consequently, most of the fluid went into the petals of the structure, generating a turbulent flow. Furthermore, the volume between the two chips was filled with only a small portion of the incoming fluid, the motion of which was hardly moved by the effect of the pump (Fig. S1c). In a first approximation model, these results can be extended to the particles in solution pumped in the inflow port; mirroring the actual experimental conditions. As a consequence, most of the particles would not flow between the observation window, but instead be trapped in the flower petal reservoir. These findings strongly suggest that parameters such as sample concentration and velocity at which the sample is injected into the holder have to be carefully chosen, in order to maximize the number of the particles in the viewing window area. 
bioRxiv preprint doi: https://doi.org/10.1101/2021.04.30.442083; this version posted April 30, 2021. The copyright holder for this preprint (which was not certified by peer review) is the author/funder, who has granted bioRxiv a license to display the preprint in perpetuity. It is made available under aCC-BY-NC 4.0 International license.

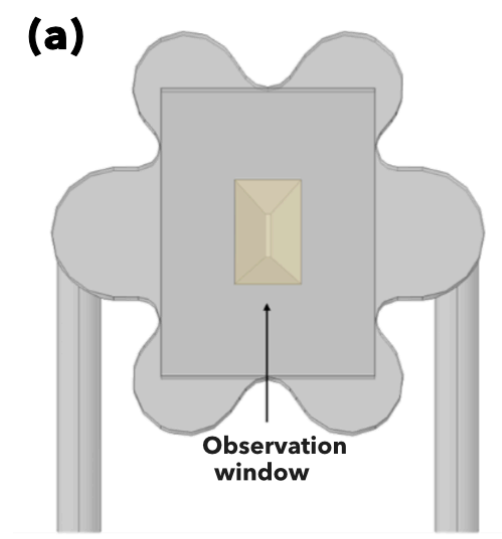

(b)

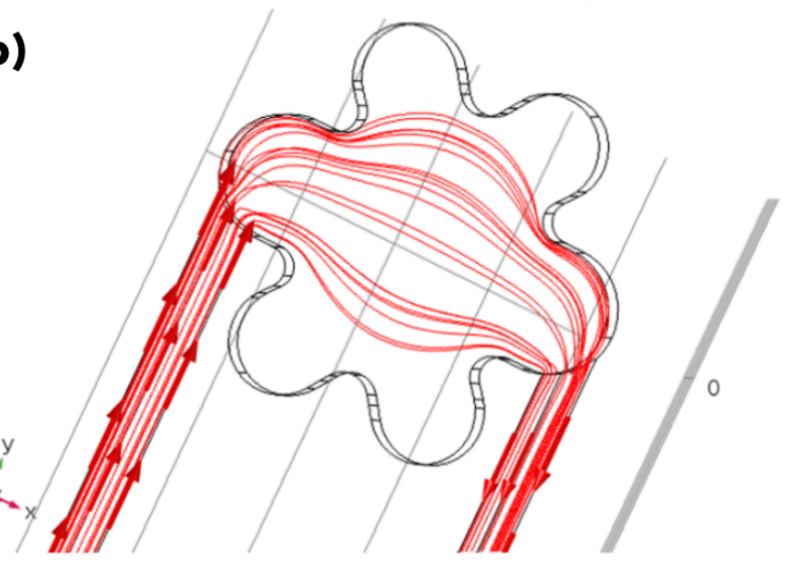

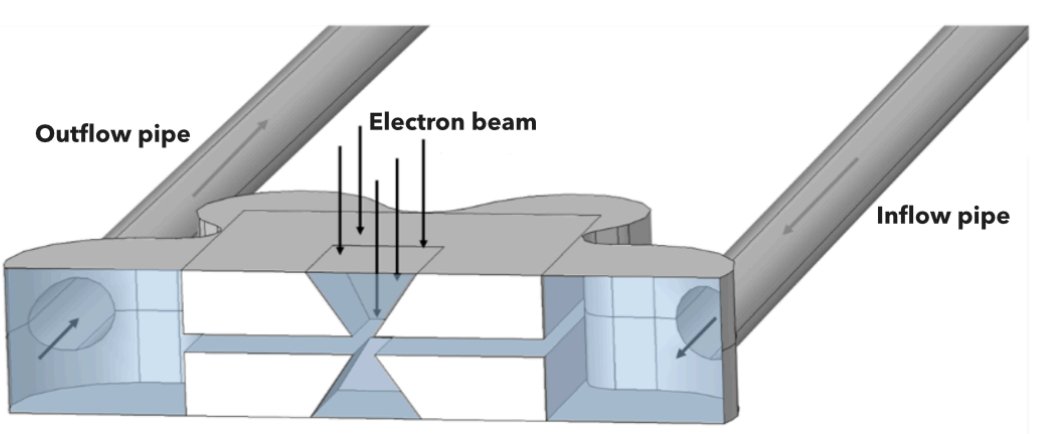

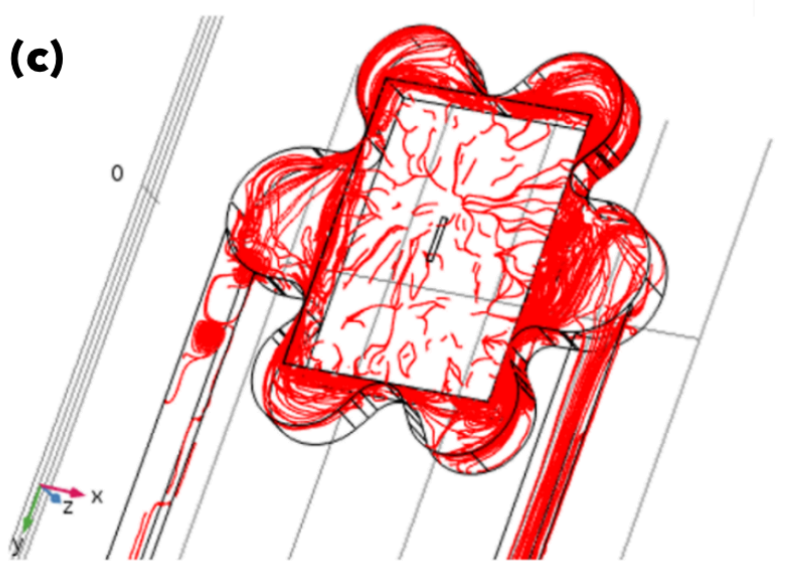

Figure S1. Liquid cell holder. Schematics of the liquid holder used for imaging liquid sample by transmission electron microscopy (a). Fluid dynamics simulations of the holder, modelled without the SiN chips (b). A Newtonian fluid was pumped in the inflow pipe (on the left) and out from the outflow pipe (on the right). The flow expands towards the flower shape reservoir perpendicular to the liquid main trajectory while flowing through the chamber. Fluid dynamics simulations of the holder comprising two chips inside (c). Both simulations run applying laminar flow, planar symmetry and no slip conditions; the analysis was then performed at steady state. 
bioRxiv preprint doi: https://doi.org/10.1101/2021.04.30.442083; this version posted April 30, 2021. The copyright holder for this preprint (which was not certified by peer review) is the author/funder, who has granted bioRxiv a license to display the preprint in perpetuity. It is made available under aCC-BY-NC 4.0 International license.

(a)

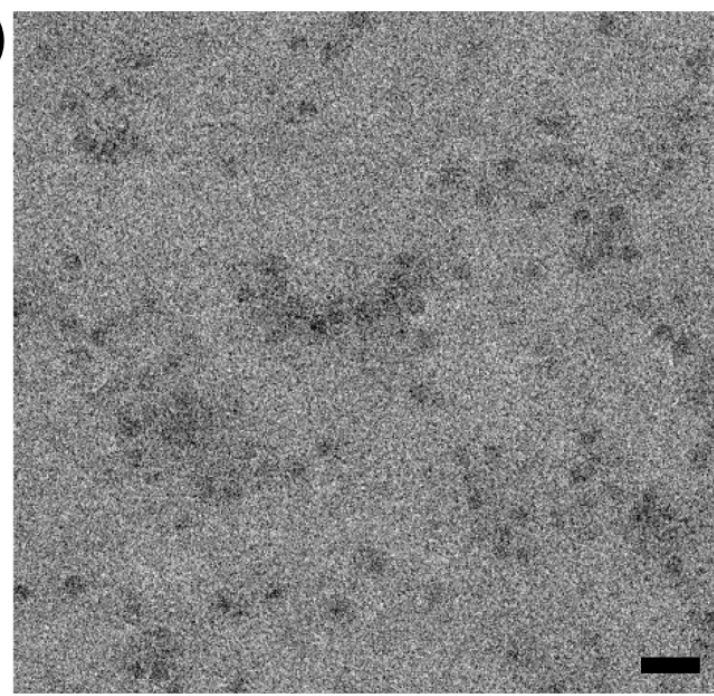

(c)

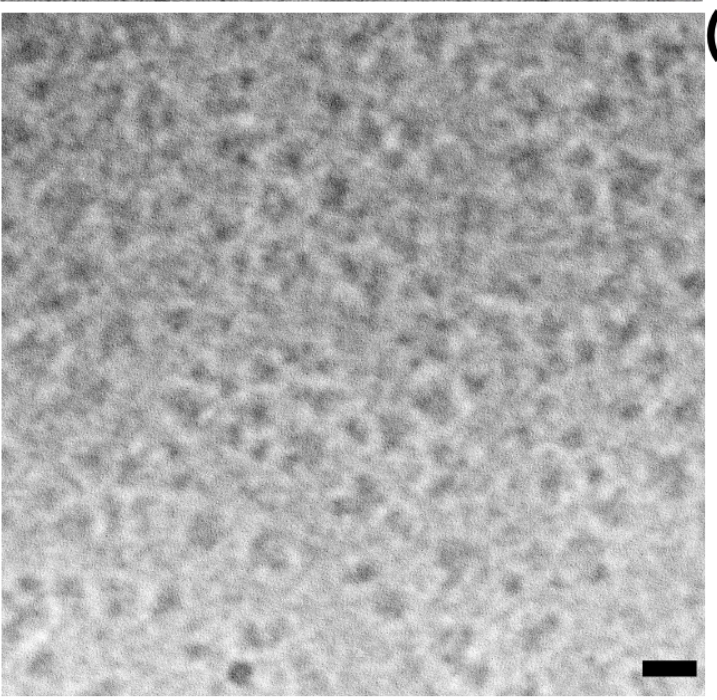

(b)
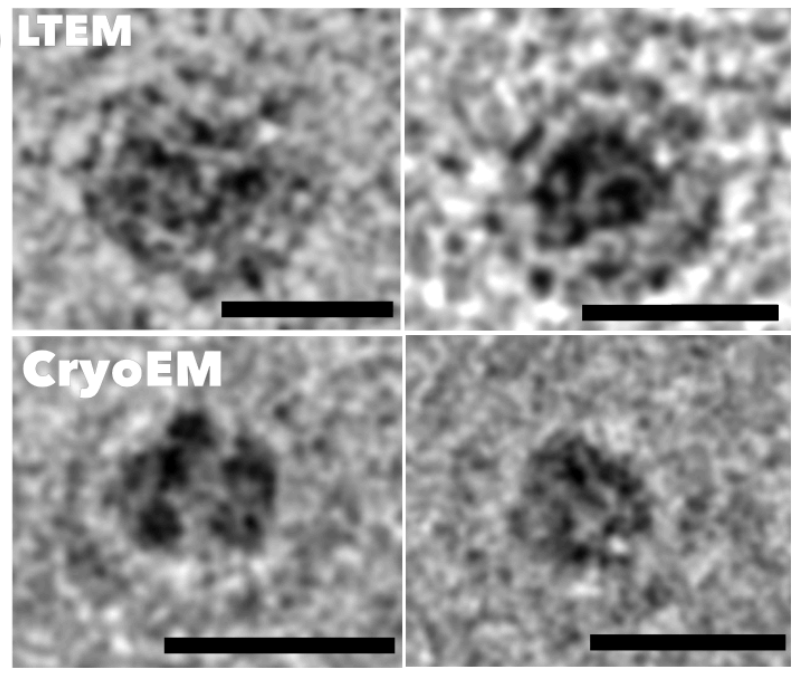

(d)

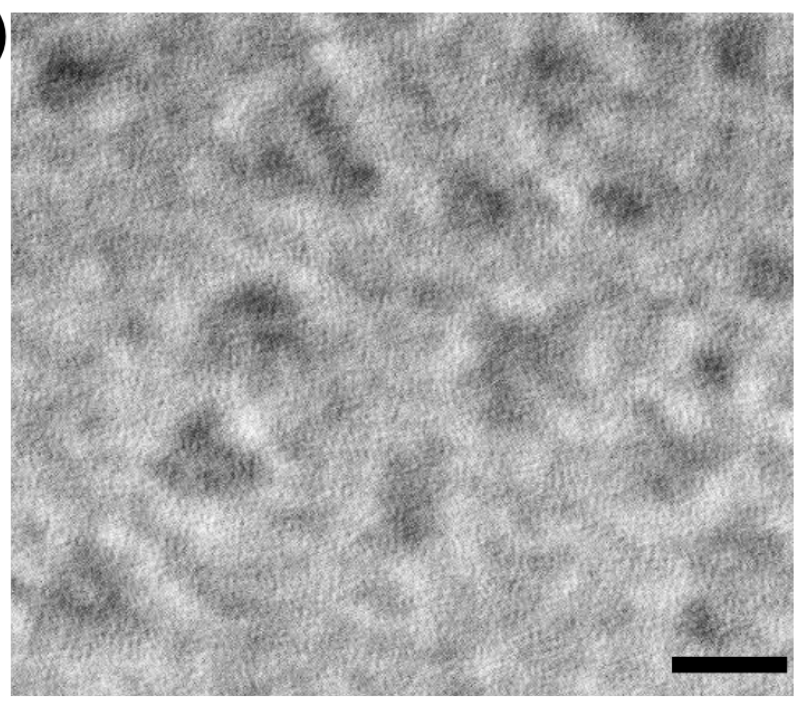

Figure S2. Liquid phase transmission electron microscopy (LPEM) imaging of proteins. LPEM micrographs of apoferritin particles collected at 20 frame per second (fps) and electron cumulative dose $<10$ e/Å2 (a). High magnification transmission electron micrographs (b) of apoferritin imaged in liquid and vitrified water. LPEM micrographs of archeal RNA polymerase particles collected at 10 frame per second (fps) in liquid water shown at low $(\mathbf{c})$ and high $(\mathbf{d})$ magnification with cumulative dose $<10$ e/ $\AA^{2}$. Scale bars: $20 \mathrm{~nm}$ 
bioRxiv preprint doi: https://doi.org/10.1101/2021.04.30.442083; this version posted April 30, 2021. The copyright holder for this preprint (which was not certified by peer review) is the author/funder, who has granted bioRxiv a license to display the preprint in perpetuity. It is made available under aCC-BY-NC 4.0 International license.

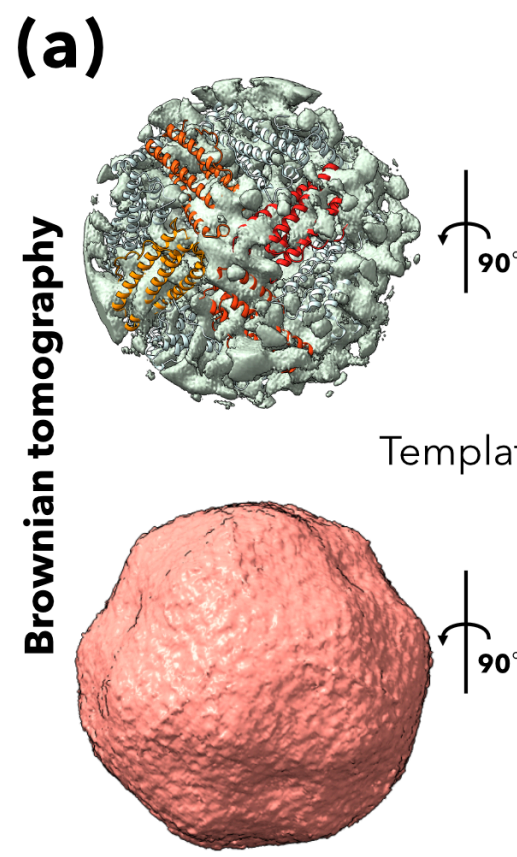

\section{No constrains}

(a)

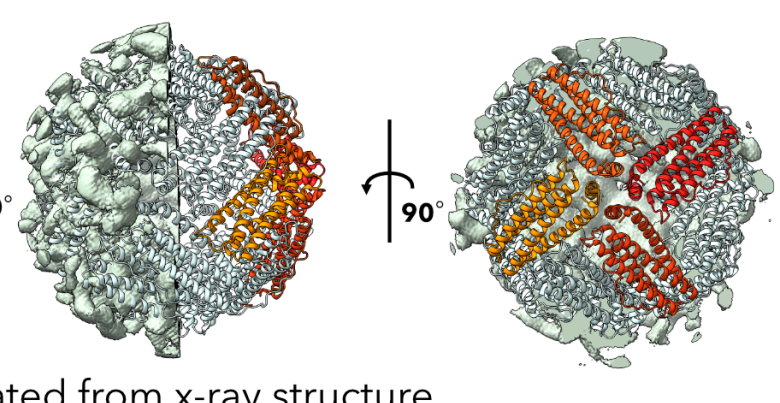

\section{(b)}
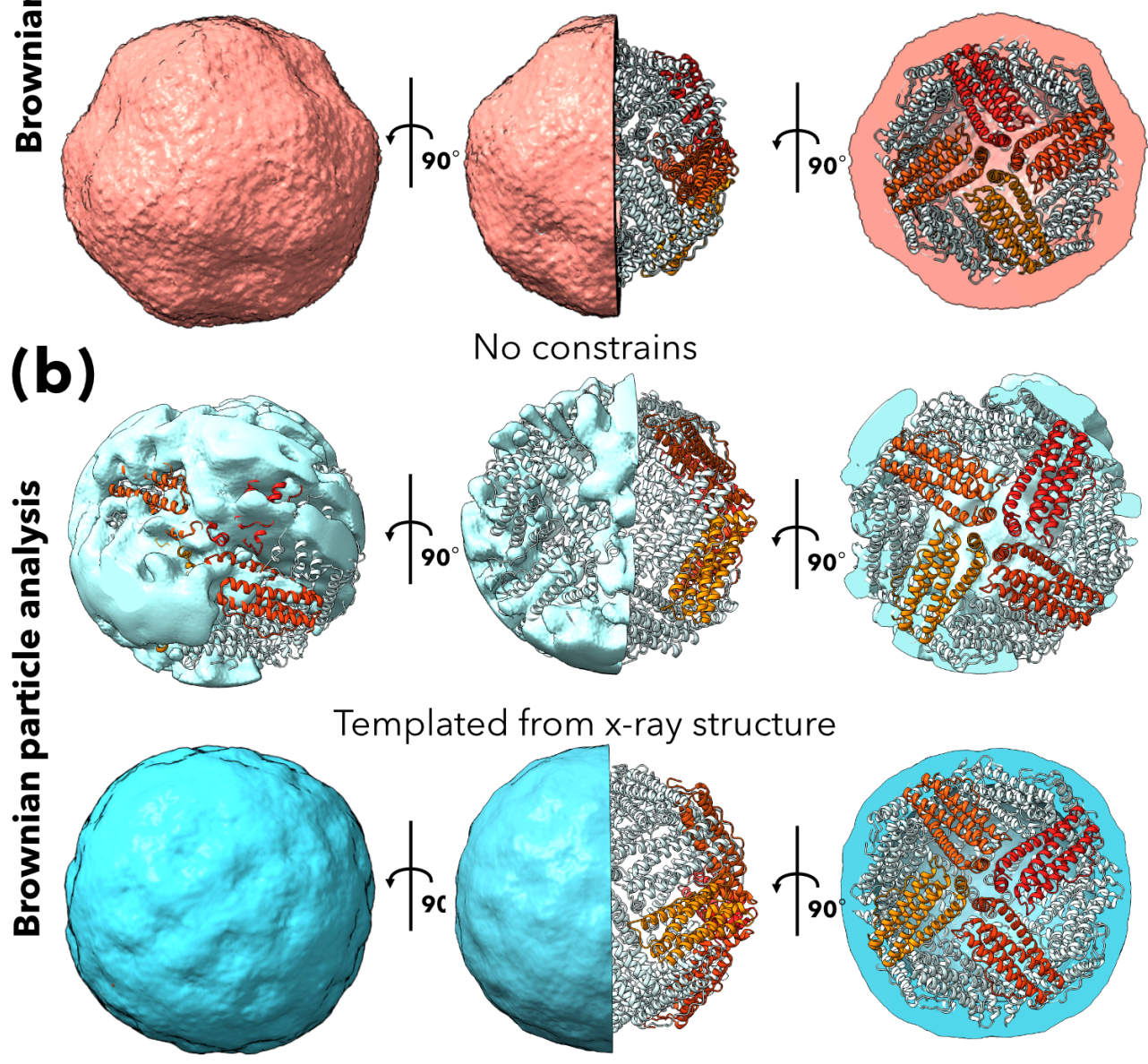

No constrains

Figure S3. Brownian tomography (BT) versus Brownian particle analysis (BPA). Comparison between electron density (ED) maps for apoferritin generated by means of both a) BT and b) BPA using either unbiased refinement or a low-pass filtered ED map calculated from the deposited $x$-ray apoferritin PDB structure, shown at different orientation. 
bioRxiv preprint doi: https://doi.org/10 1101/2021.04 30.442083; this version posted April 30, 2021. The copyright holder for this preprint (which was not certified by peer review) is the author/funder, who has granted bioRxiv a license to display the preprint in perpetuity. It is made available under aCC-BY-NC 4.0 International license.

(a)

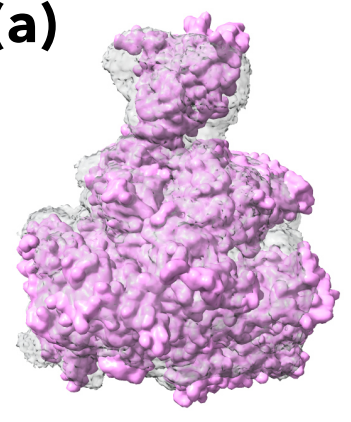

(b)

\section{(c)}

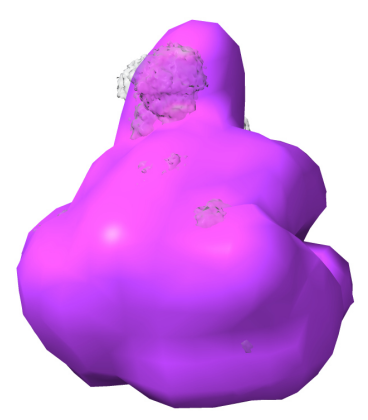

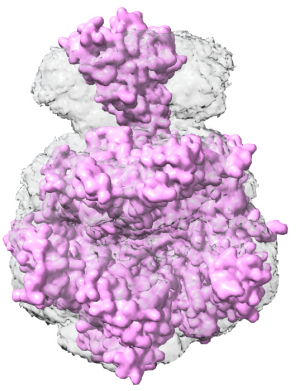
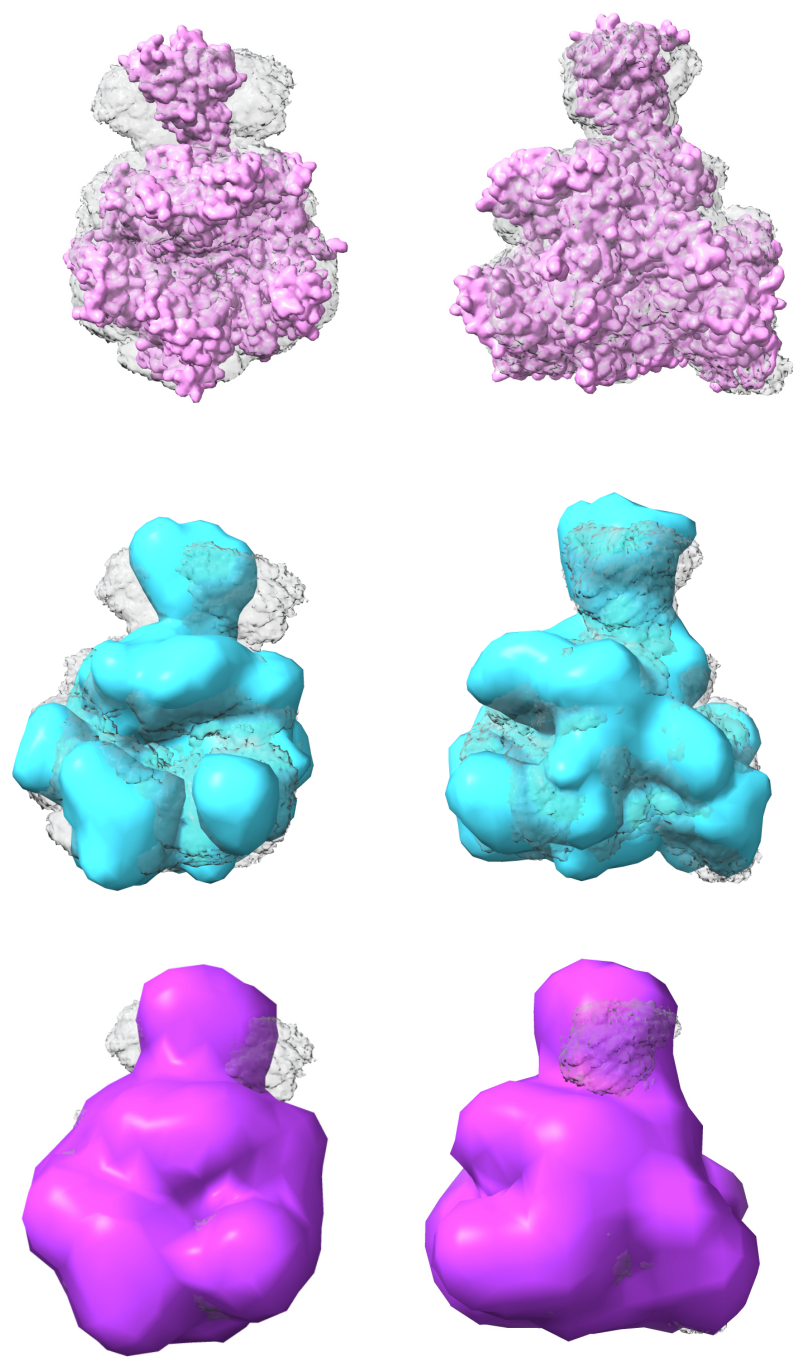

Figure S4. Static versus Dynamical maps. Three different low-pass-filtered maps of the all-atom structure of the Archeal RNA polymerase generated from Cryo-EM are depicted as surface, overlayed onto the 'dynamical map', and shown at different orientations (left, center and right hand side).Each map corresponds to the following resolutions: a) $5 \AA$, b) $20 \AA ̊$ and c) $40 \AA$. show three different orientations

\begin{tabular}{|c|c|}
\hline Resolution (Å) & Correlation \\
\hline 5 & 0.7479 \\
\hline 20 & 0.8662 \\
\hline 40 & 0.8523 \\
\hline 60 & 0.8122 \\
\hline 80 & 0.7714 \\
\hline
\end{tabular}

Table S1. Correlation between 'dynamical map' and 'static map' at different resolutions 